\title{
RESUMO DE TESE
}

\section{EFEITO DE SUPERINFECÇÕES NA EVOLUÇÃO DA DOENÇA DE CHAGAS EXPERIMENTAL COM ESTOQUES E CLONES DE TRYPANOSOMA CRUZI GENETICAMENTE CARACTERIZADOS}

Este trabalho foi iniciado pelo isolamento de estoques de $T$. cruzi, por xenodiagnóstico, de pacientes portadores das formas cardíaca (SLU239) e digestiva (SLU-142) da doença de Chagas. Desses estoques foram obtidos dois clones do SLU-239, originado do paciente com a forma cardíaca, e quatro clones do SLU-142, originado do paciente portador de megaesôfago.

Estoques e clones foram submetidos a caracterização comportamental, bioquímica e molecular. O tempo de duplicação em IIT separou-os em três grupos: Grupo I, TD longo de 87,2 a 124,8 h (clones 31, derivado do SLU-239; e clone 32, derivado do SLU-142); Grupo II, TD médio de 56,4 a $65,6 \mathrm{~h}$ (estoques e clone 34 derivado do SLU-142); Grupo III, TD curto de 37,5 a 38,2 h (clones 43 e 44 do SLU-142, e clone 22, derivado do SLU-239). A virulência dos estoques e clones, avaliada pelas curvas de parasitemia e mortalidade, permitiu caracterizar dois grupos polares. O Grupo I, de baixa virulência, incluiu os estoques e os clones derivados do SLU-239; o Grupo II, de alta virulência, formado pelos clones 32, 34, 43 e 44 derivados do estoque SLU-142. Não foi possível estabelecer correlação entre niveis de parasitemia e taxas de crescimento em LIT indicadas pelo tempo de duplicação.

$O$ estudo histopatológico feito ao longo das infecções de camundongos com estoques e clones mostrou consistente miotropismo. Porém, os estoques produziram menos parasitismo no coração que os seus clones. As lesões inflamatórias do miocárdio foram, também, mais precocemente observadas e mais acentuadas nos camundongos inoculados com os clones do que com os estoques. Os clones derivados do estoque de $T$. cruzi do paciente com a forma cardíaca da doença produziram lesões de intensidade menor que aqueles clones originados do estoque isolado do paciente com megaesôfago. Somente esses últimos produziram

Recebido para publicação em 20/12/94.

\section{EFFECTS OF SUPERINFECTIONS IN THE EXPERIMENTAL CHAGAS' DISEASE WITH GENETICALLY CHARACTERIZED TRYPANOSOMA CRUZI STOCKS AND CLONES}

This work was initiated by the xenodiagnostic isolation of $T$. cruzi from patients with the cardiac (SLU-239) or digestive (SLU-142) form of Chagas' Disease. Two clones were derived from parasite stock SLU-239 and four clones from stock SLU-142.

T. cruzi stocks and clones have been submitted to behavioural, biochemical and molecular characterizations. The parasite duplication time (DT) in LIT medium identified three groups: I, late DT from 87.2 to $124.8 \mathrm{~h}$ (clone 31 derived from SLU-239 and clone 32 derived from SLU-142); II, medium DT from 56.4 to $65.6 \mathrm{~h}$ (both stocks and clone 34 derived from SLU-142); III, early DT from 37.5 to $38.2 \mathrm{~h}$ (clones 43 and 44 derived from SLU 142, and clone 22 derived from SLU-239). The virulence of the stocks and clones, determined by parasitemia and mortality, allowed the characterization of two polar groups: I, low virulence (both stocks and clones derived from SLU-239); II, high virulence (clones 32, 34, 43 and 44, derived from SLU-142). These results do not allow us to draw any correlation between levels of parasitemia in mice and parasite growth in LIT medium.

The histopathological studies carried out through the course of infection of mice with the stocks and clones of $T$. cruzi showed marked myotropism. The parental stocks generally showed less parasitism of heart tissue than their clones. Very intensive inflammatory lesions were observed earlier in the myocardium of mice infected with the $T$. cruzi clones, whereas moderate lesions were seen later in mice infected with the parental stocks. However, the T. cruzi clones derived from the patient with the cardiac form of the disease showed lesions of a lower intensity than those seen in the hearts of mice infected with clones derived from the patient with megaesophagus. Only the latter T. cruzi clones showed marked myositis and neuritis in 
Resumo de Tese. Lauria-Pires L. Efeito de superinfecções na evolucão da doença de Chagas expertmental com estoques e clones de Trypanosoma cruzi geneticamente caracterizados. Revista da Sociedade Brasileira de Medicina Tropical 28:295-300, jul-set, 1995.

miosite e neurite intensas em camundongos $\mathrm{BALB} / \mathrm{c}$. As lesões inflamatórias no intestino grosso também foram mais evidentes nos camundongos inoculados com o estoque SLU142 e seus clones.

A diversidade de comportamento biológico dos estoques e clones foi consistente com a diversidade genética encontrada quando se analisou os marcadores fenotípicos e genotípicos das populações. A esse respeito, os fenótipos encontrados foram similares àqueles descritos por Miles e cols (1977) e por Romanha (1982). Assim, o estoque SLU-239 (forma cardíaca) mostrou perfis isoenzimáticos semelhantes ao Z3 em 9 de 13 enzimas analisadas. Este estoque diferiu de seus clones em 10 de 13 enzimas. Esses clones apresentaram perfis semelhantes ao $\mathrm{Z} 2 \mathrm{e}$ ZA. A identificação do perfil isoenzimático de Z3 no estoque SLU-239 (forma cardíaca) corresponde ao primeiro caso Z3 identificado em paciente da forma crônica cardíaca. $O$ estoque SLU-142 (forma digestiva) e seus clones exibiram perfis idênticos entre si e semelhante ao $\mathrm{Z} 2 \mathrm{em}$ 10 de 13 enzimas e ao ZA em 9 de 12 enzimas estudadas. Em resumo, os clones da forma cardíaca diferiram daqueles da forma digestiva em 3 das 13 enzimas (GPI, G6PD, ASAT).

A técnica RFLP indicou polimorfismos nos sítios de restrição obtidos com EcoRI e PstI nas seqüências de DNA que codificam as enzimas glicolíticas ALD, GPI, GAPDH e PYK. De acordo com os alelos obtidos, estoques e clones foram divididos em três grupos. O Grupo I incluiu o estoque SLU-239 e o clone 44, derivado do estoque SLU-142, como homozigoto CC, BB, AA e AA para os genes ALD, GPI, PYK e GAPDH, respectivamente. O Grupo II incluiu os clones 22 e 31 derivados do estoque SLU-239 e o estoque SLU-142 interpretados como homozigotos AA e BB para GPI e GAPDH, respectivamente, e como heterozigotos AC para os genes ALD e PYK. O Grupo III incluiu três clones da forma digestiva (clones 43, 32 e 34) com perfis homozigotos AA, AA e BB para ALD, GPI e GAPDH. Diferentes perfis obtidos para PYK subdividiu este grupo no subgrupo III A em que, os clones 43 e 42, comportaram-se como heterozigotos $\mathrm{BC}$ e o clone 34 exibiu perfil homozigoto CC. As diferenças entre clones da forma cardíaca e digestiva e, também, entre clones derivados de um mesmo estoque foram melhor evidenciadas pela técnica RFLP. Desta maneira, as isoenzimas separaram as populações em dois grupos e o RFLP indicou quatro grupos. Os quatro clones derivados do estoque SLU-142 (forma digestiva), que exibiram perfis isoenzimáticos similares,
$\mathrm{BALB} / \mathrm{c}$ mice. Inflammatory lesions in the large bowel were also very intensive in mice infected with the SLU-142 and derived clones.

The diversity of biological behaviour of $T$. cruzi stocks and clones was consistent with the phenotypic and genotypic diversities shown in the parasite populations. In this study, phenotypic profiles similar to those described by Miles et alii (1977) and Romanha (1982) were described. The SLU-239 stock showed isoenzymic profiles similar to $Z 3$ in 9 out of the 13 enzymes analysed. There were differences in 10 out of 13 enzymes among this stocks and its derived clones. All these clones showed profiles $Z 2$ and $Z A$. This is the first time that the $Z 3$ profile has been identifyied in $T$. cruzi SLU-239 derived from a chronic cardiac disease patient. The $T$. cruzi SLU-142 and its clones showed profiles similar to $Z 2$ in 10 out of 13 enzymes, and similar to $\mathrm{ZA}$ in 9 out of 12 enzymes. In brief, the clones of the parasite derived from the cardiac disease patient were different from those obtained from the megaesophagus patient in 3 out of 13 enzymes (GPI, G6PD and ASAT) studied.

Polymorphisms were shown by RFLP using the restriction enzymes Eco RI and Pst1, and DNA probes encoding the glycolytic enzymes ALD, GPI, GAPDH and PYK. According to the alleles shown, stocks and clones have been divided in three groups: I, stock SLU-239 and clone 44 derived from SLU-142 which are homozygous at $\mathrm{CC}, \mathrm{BB}, \mathrm{AA}$ and AA for the ALD, GPI, GAPDH and PYK probes respectively. Group II, included clones 22 and 31, derived from SLU-239, and stock SLU-142 which are homozygous at AA and $\mathrm{BB}$ for GPI and GAPDH probes respectively, and heterozygous at AC for the AID and PYK probes. Group III, included clones 43, 32 and 34, derived from SLU-142 with homozygous profiles AA, AA and $\mathrm{BB}$ for the ALD, GPI and GAPDH probes. The different profiles shown by PYK allowed this group to be subdivided in III A, in which clones 43 and 32 were heterozygous $\mathrm{BC}$ and clone 34 was homozygous $\mathrm{CC}$. The differences among clones derived from the cardiac and digestive forms of Chagas' disease and, also, among clones derived from the same stock, have been clearly shown by RFLP. In fact, the isoenzymes separated the parasite populations in two groups, whereas 

estoques e clones de Trypanosoma cruzi geneticamente caracterizados. Revista da Sociedade Brasileira de Medicina Tropical 28:295-300, jul-set, 1995.

foram separados pela técnica RFLP em três distintos perfis. A técnica RFLP foi, portanto, mais sensível para caracterizar estoques e clones de T. cruzi.

Os achados descritos, neste e em outros trabalhos na literatura, indicam que estoques mistos obtidos de pacientes chagásicos fornecem clones de $T$. cruzi com ampla variação comportamental e genética. Os estoques e clones de $T$. cruzi, que tiveram características comportamentais fenótipicas e genotípicas determinadas, foram empregados em experimentos de superinfecção. Entretanto, não foi possível correlacionar todos os marcadores comportamentais e moleculares para separar distintamente estoques e clones. Por isso, a ordem de inoculação das populações de T. cruzi, nos experimentos de superinfecção de camundongos foi indicada, em última análise, pela combinação da virulência com determinado perfil RFLP do DNA do parasito.

Grupos e subgrupos de camundongos isogênicos, primoinfectados com $T$. cruzi, foram submetidos a uma ou duas superinfecções com estoque ou clone do parasito geneticamente diversos, aos 30, 60 e 180 dias. Animais primoinfectados serviram como controle. As superinfecções produziram niveis parasitêmicos baixos durante 15 a 20 dias. Os percentuais de mortalidade cumulativa, nos diversos grupos de camundongos superinfectados, não foram estatisticamente diferentes daqueles observados nos animais controles primoinfectados.

Análise histopatológica realizada sincronicamente, ao longo de 12 meses de infecção nos grupos de animais primoinfectados e superinfectados, permitiu comparação dos achados nos diversos grupos experimentais. Embora algumas observações pontuais indicassem inflamação de maior intensidade em animais superinfectados, contudo, elas não persistiram ao longo das superinfecções. Esse aspecto, pois, só foi observado no período próximo ao desafio. Em resumo, não encontramos diferenças nas lesões histopatológicas, nos diversos tecidos e órgãos de camundongos primo e superinfectados, quando examinados pareadamente no mesmo período da infecção chagásica.

Grupos de coelhos, inoculados com o estoque SLU-239 (forma cardíaca) e superinfectados com $T$. cruzi do estoque SLU-142 (forma digestiva), foram analisados clínica e laboratorialmente, e os resultados comparados com aqueles de animais apenas primoinfectados the RFLP showed four groups. The clones derived from the megaesophagus patient showed similar isoenzymatic profiles, but they have been separated by RFLP in three distinct profiles. The RFLP method, therefore, appeared to be more sensitive than the isoenzymes in evaluating genetic changes in $T$. cruzi stocks and clones.

Findings in the literature indicate that mixed T. cruzi populations obtained from Chagas' patients will yield clones with broad behavioural and genetic differences. It has been difficult to separate the stocks and clones precisely with the few markers used. In this study, therefore, the parasite stocks and clones, which were identified by behavioural, phenotypic and genotypic markers, were used to superinfect of animal hosts. These analyses indicated the order of inoculation of the parasite in the superinfection experiments, according to the virulence and RFLP profiles shown.

Several groups and subgroups of isogeneic $\mathrm{BALB} / \mathrm{c}$ mice infected with $T$. cruzi were subjected to superinfection with the genetically diverse parasite stocks and clones, at 30,60 and 180 days. Animals which were primeinfected only, were used as controls. Generally, superinfection induced low parasitemia that lasted 15 to 20 days. Mortality rates in the superinfected animals were not statistically different from those of the control groups.

The histopathological comparative analysis performed synchronously through 12 months of infection, in primeinfected as well as superinfected animals, showed recrudescence of inflammatory lesions soon after superinfection. However, these features did not persist in the late period of infection. These findings indicate that there are no differences among the histopathological lesions in several organs and tissues of $T$. cruzi primeinfected and superinfected mice examined in parallel through the course of chronic infection.

It has also been shown that rabbits infected with the SLU-239 (cardiac form) and superinfecated with the SLU-142 (digestive form) $T$. cruzi stock did not demonstrate higher mortality ratio than the animals which received one infection only. Primeinfected rabbits 
Resumo de Tese. Lauria-Pires L. Efeito de superinfeç̧ões na evolucão da doença de Chagas experimental com estoques e clones de Trypanosoma cruzi geneticamente caracterizados. Revista da Sociedade Brasileira de Medicina Tropical 28:295-300, jul-set, 1995.

ou, ainda, com os coelhos controle sadios. Nos coelhos submetidos à infecção única, com qualquer estoque, houve negativação dos xenodiagnósticos após 150 dias da infecção. Coelhos superinfectados, na fase aguda, mostraram prolongamento da parasitemia. Nos animais superinfectados na fase crônica houve parasitemia transitória entre $07^{\circ}$ e $15^{\circ}$ dia após as reinfecções.

A persistência da infecção chagásica, na ausência de parasitemia demonstrável, observada tanto em animais com infecção única como em superinfectados, era indicada pela presença de altos títulos de anticorpos humorais específicos avaliados pela reação de hemaglutinação indireta e ELISA. Não houve importante variação nos títulos de anticorpos IgG detectados por estas técnicas quando se compararam os resultados obtidos de animais primo e superinfectados.

Reação cutânea endurada, no sítio de inoculação do antígeno T12E, foi observada em coelhos infectados. As reaçōes eram mais intensas nas duas primeiras semanas e durante a fase crônica. A intensidade da reação cutânea de hipersensibilidade tardia antígeno específica não diferenciou animais primoinfectados e superinfectados. Contudo, coelhos superinfectados que tiveram parasitemias patentes de longa duração apresentaram reações cutâneas de intensidade minima ou não reagiam.

Alterações eletrocardlográficas consistentes com miocardite foram registradas em $\mathbf{8 8 , 6 \%}$ dos coelhos infectados com T. cruzi. De interesse, o percentual de ECGs alterados fol similar nos coelhos primo e superinfectados. As alteraçōes eletrocardiográficas apresentadas pelos coelhos evoluiram lentamente durante a fase crônica da infecção pelo T. cruzi, Enfim, os diversos tipos de alterações eletrocardiográficas apareceram indistintamente nos grupos de coelhos primoinfectados e superinfectados.

Alterações eletrocardiográficas tiveram correlação negativa com a parasitemia. Entretanto, houve correlação positiva entre morbidade indicada por alterações do ECG e intensidade das reações cutâneas tardias ao antígeno $\mathrm{T} 12 \mathrm{E}$ do $T$. cruzi. $\mathrm{O}$ teste cutâneo, portanto, parece ser um indicador de dano miocárdico.

A sintomatologia da infecção experimental de coelhos pelo $T$. cruzi não foi diferente nos grupos de animais primoinfectados e superinfectados. Um coelho primoinfectado apresentou crises convulsivas generalizadas quando tinha parasitemia demonstrável pela demonstrated parasitemia for 150 days, while rabbits superinfected in the acute phase demonstrated parasitemia for a longer period, and the rabbits superinfected in the chronic phase showed only transient parasitemia between the 7 th and the 15 th days.

The persistence of the Chagas' infections, in the absence of demonstrable parasitemia, was shown by the presence of high antibody titers by indirect hemagglutination and ELISA. No difference has been shown in antibody titers among primeinfected and superinfected rabbits. An indurated, delayed-type skin lesion at the site of injection of the $T$. cruzi T12E antigen was shown in chagasic rabbits. The intensity of these reactions were higher in the early weeks and in the late chronic phase of infection. It was also shown that the intensity of the antigen-specific, delayed-type skin reaction was not different in primeinfected and superinfected rabbits. However, those superinfected rabbits which demonstrated long lasting parasitemia showed minimal skin reactions or did not react at all.

ECG alterations consistent with Chagas' myocarditis were recorded in $88.6 \%$ of T.cruziinfected rabbits. Interestingly, the percentage of altered ECGs was similar in prime and superinfected animals. All the ECG alterations progressed slowly through the chronic phase of infection, regardless of whether the animal was prime or superinfected. In summary, the ECG alterations appeared to be similar in all groups of T. cruzt-infected rabbits. It is interesting to note that the ECG alterations show a negative relationship to parasitemia. However, there was a positive relationship between morbidity, as shown by ECG changes, and the intensity of skin reactions to the parasite $\mathrm{T} 12 \mathrm{E}$ antigen. It appears, therefore, that the skin test is a usefull marker for myocardial damage.

The symptoms shown by $T$. cruzi-infected rabbits were similar in primeinfected and superinfected experimental groups. One $T$. cruzi-infected rabbit showed generalized seizures, at the period of infection with demonstrable parasitemia in $90 \%$ of the triatomine bugs used in xenodiagnosis. This rabbit survived the acute phase of Chagas' 
Resumo de Tese. Lauria-Pikes l. Efeito de superinfeç̧öes na evolucão da doença de Chagas experimental com estoques e clones de, TFypanosoma cruzi geneticamente caracterizados. Revista da Sociedade Brasileira de Medicina Tropical 28:295-300, jut-set, 1995 . sh:

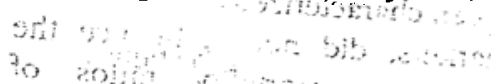

$$
\begin{aligned}
& \text { 2tchlo }
\end{aligned}
$$

positividade de $90 \%$ dos triatomíneos utilizados no xenodiagnóstico. $O$ animal sobreviveu à fase aguda sendo reinfectado no $300^{\circ}$ dia após a inoculação inicial.

Independentemente do coelho ser primoinfectado ou superinfectado, a morte súbita ocorreu num percentual de $14.3 \%$. A análise histopatológica, nesses casos, sempre revelou miocardite e comprometimento do sistema de condução intracardíaco. Processos inflamatórios do miocárdio foram observados em 94,1\% dos 17 coelhos infectados com $T$. cruzi que faleceram no curso da infecção. Esses infiltrados eram difusos ou focais, e caracterizados por células mononucleares, associados a lise de fibras cardíacas. A intensidade da inflamação foi similar entre os grupos de coelhos primoinfectados e superinfectados, e o parasito não foi encontrado nos tecidos. A fibrose miocárdica era semelhante nos diferentes grupos de animais inoculados, cuja intensidade variava com o período da infecção. As lesões no esôfago, intestino grosso e músculos esqueléticos foram sempre discretas, independentemente do estoque utilizado na primoinfecção e do animal ser ou não superinfectado. Nas secções examinadas não foram encontradas formas amastigotas do $T$. cruzi.

Em resumo, após 35 meses de observação, os indices de mortalidade observados nos coelhos primoinfectados não foram estatisticamente diferentes daqueles indices registrados nos grupos de coelhos superinfectados. Assim, as superinfecções não alteraram a morbidade evidenciada pelas alteraçôes eletrocardiográficas, nem a mortalidade dos animais, cujas lesões histopatológicas não permitem distinguir coelhos primo e superinfectados.

A caracterização das populações de $T$. cmuzi reisoladas permitiu estabelecer que os parasitos usados nos inóculos estavam presentes nos animais superinfectados. Os perfis das curvas de parasitemia foram consistentes com o reisolamento de mais de uma população. Entretanto, os perfis não eram semelhantes àqueles obtidos com cada estoque ou clone separadamente. Por outro lado, a caracterização fenotípica das populações reisoladas, através de quatro enzimas solúveis (GPI, G6PD, 6PGD e PGM) foi compativel com o reisolamento de apenas uma população. Em contraste, a técnica RFIP indicou, ou mesmo demonstrou, a presença de mais de uma população nos reisolados mistos. Deste modo, o RFLP foi melhor marcador de populações de $T$. cmuzi. disease and became superinfected 300 days after the initial parasite inoculation.

Fourteen and three per cent of the Chagas' rabbits died suddenly regardless of whether they were prime or superinfected. The histopathological study showed myocarditis involving the intracardiac conducting system. Inflammatory lesions were seen in $94.1 \%$ of $17 T$. cruzi-infected rabbits that died during the course of the infection. These inflammatory lesions were focal or diffuse, and characterized by mononuclear cell infiltrates associated with cardiac fiber lysis. The intensity of the lesions was similar, and varied with the period of the infection in all experimental groups. No parasite was found in the tissue lesions. The fibrotic lesions were also similar in all groups of experimental animals. The lesions in the large intestine and skeletal muscles were usually discrete, and did not vary with the T. cruzi-stock used in the prime and superinfections.

In summary, after 35 months of observation, the mortality rates in primeinfected rabbits were not statistically different from those recorded in the groups of superinfected rabbits. The T. cruzisuperinfections, therefore, neither altered morbidity, as shown by ECG recordings, nor increased mortality in rabbits. The histopathologic lesions in both groups of rabbits were indistinguishable.

The behavioural, biochemical and molecular characterization of $T$. cruzi populations recovered from chagasic mice and rabbits showed the same profiles as those shown by the parasites used to prime and superinfect the experimental animals. The profiles of curves of parasitemia were consistent with the information that more than one population had been recovered. However, those profiles were not similar to those seen when each parasite stock or clone was used to infect animals separately. On the other hand, the phenotypic characterization of these populations, shown by four isoenzymes (GPI, G6PD, 6PGD and PGM), was consistent with the information that one population only had been reisolated. In marked contrast, the RFLP's show the presence of more than one population in the reisolated parasite. In this regard, therefore, the RFLP was an useful marker to characterize these $T$. cruzi populations. 
Resumo de Tese. Lauria-Pires L. Efeito de superinfecções na evolucão da doença de Chagas experimental com estoques e clones de Trypanosoma cruzi geneticamente caracterizados. Revista da Sociedade Brasileira de Medicina Tropical 28:295-300, jul-set, 1995.

Em conclusão, este estudo mostrou que as superinfecções determinadas por estoques e clones de $T$. cruzi, separados por características comportamentais e genéticas, não influenciam na evolução clínica e na mortalidade da doença de Chagas, tanto em camundongos quanto em coelhos.
In conclusion, this study showed that superinfections with stocks and clones of $T$. cruzi, that had been characterized by behavioural and genetic markers, did not influence the clinical evolution or mortality ratios of experimental Chagas' disease in mice and rabbits.

\section{Liana Lauria-Pires}

Tese apresentada à Faculdade de Ciências da

Saúde da Universidade de Brasília para

obtenção do Título de Doutor.

Brasília, DF, Brasil, 1994. 